\title{
Study on the Reducibility and Mechanical Properties of Pellets Produced from Blends of Itakpe and Agbaja Iron Ore
}

\author{
Ocheri $\mathbf{C}^{1^{*}}$, C.N. Mbah', A.C. $\mathrm{Mbah}^{2}$ \\ ${ }^{I}$ Dept. of Metallurgical and Materials Engineering, University of Nigeria, Nsukka, Enugu State, Nigeria \\ ${ }^{2}$ Enugu State University of Science and Technology (ESUT) Enugu State, Nigeria
}

*Corresponding Author: Ocheri C, Dept. of Metallurgical and Materials Engineering, University of Nigeria, Nsukka, Enugu State, Nigeria

\begin{abstract}
The study underscored the need to carry out intense research work in this area with a view to blending a high and low grade of iron ores to be used as burden in the blast furnace and Direct Reduced Iron (DRI). The burdens materials in the furnaces with the purpose of producing molten metals. The mechanical properties also reveal the behaviour of the blends through compressive strength results (both green and dry) , Drop Number, Drop Resistance, Green Compression, Dry Compression, Moisture Content, Tumbler Index Value, Abrasion Index, Micro porosity, Drop Number, Drop Resistance, Green Compression, Dry Compression, Moisture Content, Tumbler Index Value, Abrasion Index, Micro porosity and , it is also with a view to determining the blend ratio which gave the optimum indurating compressive strength. And finally the mechanical strength of the fired pellets were determined in order to arrive at the best blend ratio of both ores for the production of molten melts from the furnaces at Ajaokuta and the Direct Reduced Iron (DRI) process at the Delta Steel Company Limited, Aldaja which operates the Midrex process.
\end{abstract}

Keywords: Reducibility, Blends, Pellets, Itakpe iron ore, Agbaja iron ore and mechanical Properties

\section{INTRODUCTION}

The budern materials in the blast furnace and the Direct reduction Iron processes cannot be over emphasized the need to througly study the reducicibilty of the iron ores to be used in the furnaces becomes very important .on the other hand of the produecd pellets from the ores used to also be determined ecomes very penitent to study some ores situated in Nigeria with particular reference to Itakpe and Agbaja iron ore The Itakpe iron ore is proven to have more iron content than the Agbaja iron ore, The resevesre estimate for the Agbaja iron ore is put to about 3.1 billion metric tonne while the Itakpe iron ore reserve is put at 300 million metric tonne. In modern blast furnace operation burden materials are developed with the aim of producing quality molten metal fron the process. It has been tested that the Agbaja iron ore cannot be used directly as feeds in the furnace, while the Itakpe iron ore could be used directly. In considering this short fall it becomes very important therefore to blend the two ores together so as to be ues as feed in both furnaces at Ajaokuta and AladjaSteel both in Nigeria. In order to achieve this the ores produced from the blends must therefore to made into pellets through the progress of palletization or pelletizing. As stated earlier the mechanical characteristics of blended iron ore pellets were investigated to evaluate the possibility of using the blend mixture to produce liquid pig iron in the blast furnace. The drop number, drop resistance, green compression strength, dry compression strength and indurating compressive strength values were used as major criteria in assessing the selected blends under study.

The characteristics of raw materials for the process and their propertis affects the quality of the products. The Direct Reduction Process is a form of process that uses metallic iron is produced by the reduction of iron ore directly to iron below its melting temperature. This process is called the Direct Reduction Iron (DRI). The Midrex shaft furnace uses iron oxide palletization of lump ores fed into the top of the furnace and the iron oxide is heated and coverted to DRI bya high temperature reducing gas. At a very recent development the operation of blast furnace are considered very critical and this necesiated the preparation of burden materials that provided for the opertation of the furnace. In considering this some basic parameters are use which the size of the burden materials, chemical compositions are also viewed as very important ingredients for the puopse of achieving oprtimal furnace productivity 
Study on the Reducibility and Mechanical Properties of Pellets Produced from Blends of Itakpe and Agbaja Iron Ore

Many researchers have investigated on the possibility of advancing on the burden materials in the operation of the furnace which have also played vital role in most aspect of the operation of the furnace for effectively producing molten metal's . To successfully operate the furnaces in Ajaokuta Steel and Delta Steel the chemical and physical compostions and properties of such burden materials must be determined with a view to ascertaining their suitability

Materials inside the furnaces must be considered as regards the performance of the furnaces is to be determined under reducing conditions ( reducibility), It must also be know that this country is blessed or end owned with lots of mineral resource which include the iron ores located in various parts of the Kogi State and some parts in Nigerian . In view of this therefore the study on the reducibility and mechanical properties of produced pellets from Itakpe and Agbaja iron ores are been investigated upon due to the fact that the Itakpe ore has high grade of iron than that of Agbaja ore. Although it has been very cumbansome to perform some tests and analyses which could be uses as simulated for the conditions for furnace operation. The furnaces have been known as the final smelting vessel that are been used for produce molten liquid using the appropriate burden materials it is therefore penitent to perform some trails in the blast furnace trials in order to assess some specific materials when they could be subjected test under some specific conditions, this is with the pupose to correlate the findings with experimental laboratory tests. To also determine the relevance ans acceptability of such burden materals they must also be subjected to various practices in furnace operation and local economics. To really test these materials they must be subjected to the process of reducibilty by allowing ease removal of oxygen from the burden materials Reducibility therefore give express information on the required to be used in the blast furnace and this also give optimum reduced size of materials to be employed during usage.

\section{MECHANICAL PROPERTIES OF BLEND ITAKPE AND AGBAJA IRON ORE}

Chemical analysis of the blends and mechanical properties of pellets were presented in Tables 2.1 and 2.2 respectively. Figures 2.01 to 2.09 are the graphs of mechanical properties of produced blended pellets.

Table2.1. Chemical Composition of Itakpe Iron Ore Concentrate

\begin{tabular}{|c|c|}
\hline Compound & Concentration (\%) \\
\hline$\left(\mathrm{Al}_{2} \mathrm{O}_{3}\right.$ & 4 \\
\hline $\mathrm{SiO}_{2}$ & 15 \\
\hline $\mathrm{K}_{2} \mathrm{O}$ & 0.15 \\
\hline $\mathrm{CaO}$ & 0.32 \\
\hline $\mathrm{V}_{2} \mathrm{O}_{5}$ & 0.02 \\
\hline $\mathrm{Cr}_{2} \mathrm{O}_{3}$ & 0.091 \\
\hline $\mathrm{MnO}$ & 0.1 \\
\hline $\mathrm{Fe}_{2} \mathrm{O}_{3}$ & 79.1 \\
\hline $\mathrm{CuO}$ & 0.0052 \\
\hline $\mathrm{Br}$ & 0.14 \\
\hline $\mathrm{Rb}_{2} \mathrm{O}$ & 0.14 \\
\hline $\mathrm{ZrO}_{2}$ & 0.26 \\
\hline $\ln _{2} \mathrm{O}_{3}$ & 0.1 \\
\hline $\mathrm{la}_{2} \mathrm{O}_{3}$ & 0.09 \\
\hline $\mathrm{P}_{2} \mathrm{O}_{5}$ & Trace \\
\hline
\end{tabular}

Table2.2. Chemical Composition of Agbaja Iron Ore Concentrate

\begin{tabular}{|c|c|}
\hline Compound & Concentration, \% \\
\hline $\mathrm{Al}_{2} \mathrm{O}_{3}$ & 12 \\
\hline $\mathrm{SiO}_{2}$ & 6.9 \\
\hline $\mathrm{P}_{2} \mathrm{O}_{5}$ & 1.3 \\
\hline $\mathrm{CaO}$ & 0.972 \\
\hline $\mathrm{TiO}_{2}$ & 0.33 \\
\hline $\mathrm{V}_{2} \mathrm{O}_{5}$ & 0.11 \\
\hline $\mathrm{Cr}_{2} \mathrm{O}_{3}$ & 0.11 \\
\hline $\mathrm{MnO} \mathrm{Fe}_{2} \mathrm{O}_{3}$ & 0.19 \\
\hline $\mathrm{CuO}$ & 74.78 \\
\hline $\mathrm{ZnO}$ & 0.034 \\
\hline $\mathrm{Br}$ & 0.054 \\
\hline $\mathrm{Re}_{2} \mathrm{O}_{7}$ & 0.23 \\
\hline
\end{tabular}


Study on the Reducibility and Mechanical Properties of Pellets Produced from Blends of Itakpe and Agbaja Iron Ore

Table2.3. Mechanical Properties of blended Itkape / Agbaja Iron ore

\begin{tabular}{|c|c|c|c|c|c|c|c|c|c|c|c|c|c|c|c|c|c|c|c|c|c|}
\hline \begin{tabular}{|c|} 
Type of \\
test \\
carried \\
out. \\
\end{tabular} & $\begin{array}{c}100.0 \\
/ 0.0\end{array}$ & $\begin{array}{c}95.0 / \\
5.0\end{array}$ & $\begin{array}{c}90.0 / 1 \\
0 / 0\end{array}$ & \begin{tabular}{|l|}
$85.0 /$ \\
15.0
\end{tabular} & \begin{tabular}{|l|}
$80.0 /$ \\
20.0
\end{tabular} & \begin{tabular}{|l|}
$75.0 /$ \\
25.0
\end{tabular} & \begin{tabular}{|l|}
$70.0 /$ \\
30.0
\end{tabular} & \begin{tabular}{|l|}
$65.0 /$ \\
35.0
\end{tabular} & $\begin{array}{l}60.0 / \\
40.0\end{array}$ & $\begin{array}{c}55.0 / \\
45.0\end{array}$ & \begin{tabular}{|l|}
$50.0 /$ \\
50.0
\end{tabular} & \begin{tabular}{|c|}
$45.0 /$ \\
55.0
\end{tabular} & \begin{tabular}{|c|}
$40.0 /$ \\
60.0
\end{tabular} & $\begin{array}{l}35.0 / \\
65.0\end{array}$ & \begin{tabular}{|c|}
$30.0 /$ \\
70.0
\end{tabular} & $\begin{array}{l}25.0 / \\
75.0\end{array}$ & \begin{tabular}{|l|}
$20.0 /$ \\
80.0
\end{tabular} & $\begin{array}{l}15.0 / \\
85.0\end{array}$ & $\begin{array}{l}10.0 / \\
90.0\end{array}$ & \begin{tabular}{|c|}
$5.0 / 9$ \\
5.0
\end{tabular} & $\begin{array}{l}0.0 / 1 \\
00.0\end{array}$ \\
\hline \begin{tabular}{|c|} 
Drop \\
Number \\
Test @ \\
$60 \mathrm{~cm}$ \\
\end{tabular} & 3.65 & 3.05 & 2.45 & 2.39 & 2.32 & 3.07 & 3.82 & 3.15 & 2.48 & 2.65 & 2.82 & 2.24 & 1.65 & 1.50 & 1.35 & 1.25 & 1.15 & 1.30 & 1.45 & 2.72 & 3.68 \\
\hline \begin{tabular}{|c|} 
Drop \\
Resistan \\
ce Test \\
$@$ \\
$48 \mathrm{~cm}$ \\
$60 \mathrm{~cm}$, \\
$72 \mathrm{~cm}$ \\
\end{tabular} & 3.65 & 3.16 & 2.82 & 2.90 & 2.98 & 2.98 & 2.98 & 3.32 & 3.65 & 4.15 & 4.65 & 3.15 & 1.65 & 1.50 & 1.35 & 1.25 & 1.15 & 1.15 & 1.15 & 2.40 & 3.65 \\
\hline \begin{tabular}{|c|} 
Green \\
Compre \\
ssive \\
Strength \\
. Test \\
$(\mathrm{N} / \mathrm{P})$ \\
\end{tabular} & 14.25 & $\begin{array}{c}13.0 \\
8\end{array}$ & 11.91 & 12.12 & 12.33 & 11.29 & 11.25 & 9.38 & 8.50 & 8.17 & 7.83 & 7.15 & 6.10 & 5.89 & 5.33 & 5.12 & 4.55 & 4.20 & 4.20 & 7.85 & 11.50 \\
\hline \begin{tabular}{|c|} 
Dry \\
Compre \\
ssive \\
Strength \\
Test @ \\
$600^{0} \mathrm{c}$. \\
$(\mathrm{N} / \mathrm{P})$ \\
\end{tabular} & 41.5 & 37.3 & 33.0 & 33.3 & 33.5 & 34.1 & 34.7 & 29.5 & 24.3 & 20.5 & 16.8 & 17.6 & $\mid 18.3$ & 16.9 & 15.5 & 15.5 & 15.4 & 14.5 & 13.5 & 23.3 & 33.0 \\
\hline \begin{tabular}{|c|}
$\begin{array}{c}\text { Indurati } \\
\text { ng }\end{array}$ \\
Compre \\
ssive \\
Strength \\
Test@ \\
$1200^{\circ} \mathrm{c}$ \\
$(\mathrm{N} / \mathrm{P})$ \\
\end{tabular} & $\begin{array}{c}2588 . \\
30\end{array}$ & $\begin{array}{c}2425 \\
.90\end{array}$ & $\begin{array}{c}2263 \\
33\end{array}$ & $\begin{array}{c}2280 . \\
00\end{array}$ & $\begin{array}{c}2296 . \\
67\end{array}$ & $\begin{array}{c}2455 . \\
00\end{array}$ & $\begin{array}{c}2613 . \\
33\end{array}$ & $\begin{array}{c}2050 . \\
83\end{array}$ & $\begin{array}{c}1488 . \\
33\end{array}$ & $\begin{array}{c}1496 . \\
67\end{array}$ & $\begin{array}{c}1505 . \\
00\end{array}$ & $\begin{array}{c}1587 \\
00\end{array}$ & $\begin{array}{c}1669 . \\
00\end{array}$ & $\begin{array}{c}1594 . \\
50\end{array}$ & $\begin{array}{c}1520 \\
00\end{array}$ & $\begin{array}{c}972.5 \\
0\end{array}$ & $\begin{array}{c}425.0 \\
0\end{array}$ & $\begin{array}{c}935.0 \\
0\end{array}$ & $\begin{array}{c}1445 . \\
00\end{array}$ & $\begin{array}{c}1175 \\
.00\end{array}$ & $\begin{array}{c}905.0 \\
0\end{array}$ \\
\hline \begin{tabular}{|c|} 
Moistur \\
$\mathrm{e}$ \\
Content \\
Per \\
Pellet(m \\
l) \\
\end{tabular} & 4.85 & 5.07 & 5.28 & 4.99 & 4.99 & 5.11 & 5.22 & 5.26 & 5.30 & 5.33 & 5.36 & 5.08 & 4.80 & 4.83 & 4.86 & 4.90 & 4.93 & 5.15 & 5.36 & 5.41 & 5.45 \\
\hline \begin{tabular}{|c|} 
Abrasio \\
n Index \\
Test (\%)
\end{tabular} & 2.49 & 3.27 & 4.05 & 5.03 & 6.04 & 8.74 & 11.46 & 9.18 & 6.89 & 11.73 & 16.56 & 10.49 & 4.41 & 4.81 & 5.21 & 4.68 & 4.15 & 4.45 & 4.75 & 5.15 & 29.37 \\
\hline \begin{tabular}{|c|} 
Micro- \\
Porosity \\
of Pellet \\
$(\%)$
\end{tabular} & 5.48 & 5.31 & 5.14 & 4.42 & 3.69 & 4.23 & 4.77 & 4.75 & 4.72 & 5.05 & 4.83 & 4.63 & 4.42 & 7.22 & 10.20 & 10.43 & 10.83 & 12.91 & 14.99 & $\begin{array}{c}10.8 \\
9\end{array}$ & 6.78 \\
\hline
\end{tabular}

As stated earlier the mechanical characteristics of blended iron ore pellets were investigated to evaluate the possibility of using the blend mixture to produce liquid pig iron in the blast furnace. The drop number, drop resistance, green compression strength, dry compression strength and indurating compressive strength values were used as major criteria in assessing the selected blends under study. The results of the mechanical properties of the blended Itakpe / Agbaja iron ores could be found in appendix I

\subsection{Drop Number}

Figure2.01 shows the variation of drop number with percentage Agbaja / Itakpe iron ore pellets. The highest drop number point was attained at $3.82 \mathrm{~cm}$.blend ratio of 70/30 Itakpe/Agbaja while the standard minimum is $4 \mathrm{~cm}$

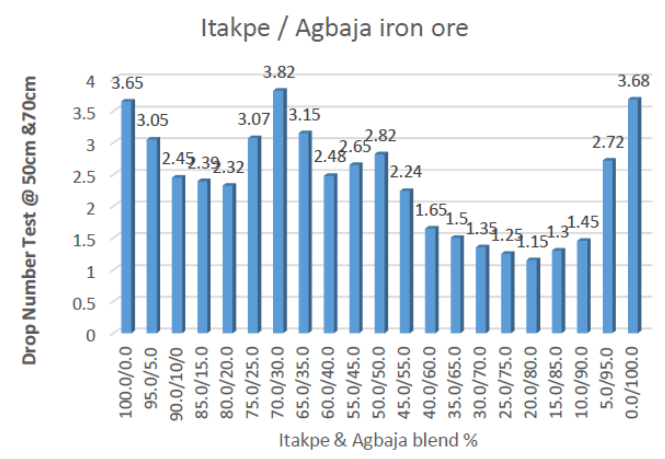

Figure2.01. variation of Drop Number with various blends of Itakpe/Agbaja Iron Ore Pellets 


\subsection{Drop Resistance}

Figure 2.02 shows variation of drop resistance with various blends of Itakpe/ Agbaja iron ore pellet. The best drop resistance was attained at Itakpe/Agbaja blend ratio of 50/50 at $4.50 \mathrm{~cm}$ when compared to the standard minimum value of $4.65 \mathrm{~cm}$ while the maximum is $5.8 \mathrm{~cm}$.

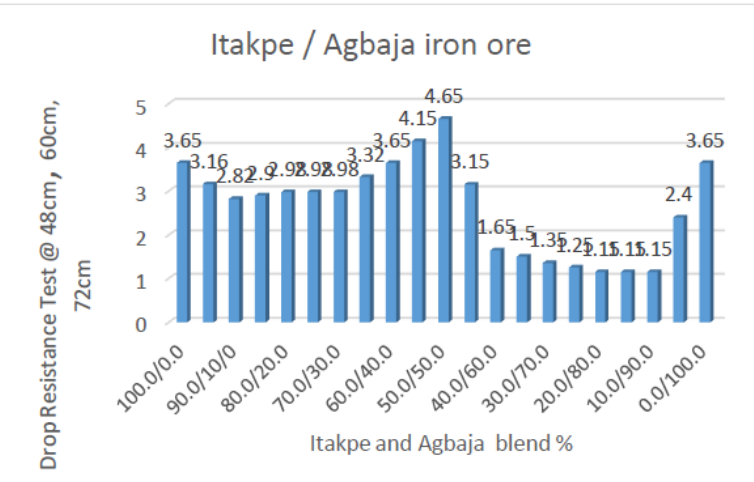

Figure2.02. Variation of Drop Resistance with various blends of Itakpe/ Agbaja Iron Ore Pellets

\subsection{Green Compression}

Figure 2.03 shows variation of Green Compressive Strength with various blends of Itakpe / Agbaja Iron Ore Pellets. The best green compression strength amongst the blend mixtures was achieved at $80 / 20$ blend ratio of Itakpe/Agbaja with a value of $12.33 \mathrm{~N} / \mathrm{P}$ when compared to the standard minimum value of $10 \mathrm{~N} / \mathrm{P}$

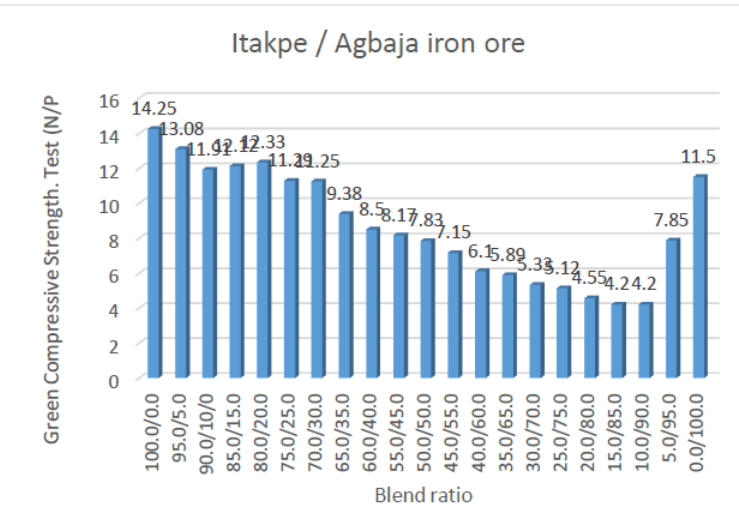

Figure2.03. Variation of Green Compressive Strength with various blends of Itakpe/Agbaja Iron Ore Pellets

\subsection{Dry Compression}

Figure2.04 shows Variation of Dry Compressive Strength with Various blends of Itakpe/Agbaja Iron Ore Pellets. In this trend the best green compression strength amongst the blend mixtures was achieved at 70/30 Itakpe/Agbaja blend ratio with green compressive strength of 34.7N/P as compared to the standard requirement value of $10 \mathrm{~N} / \mathrm{P}$.

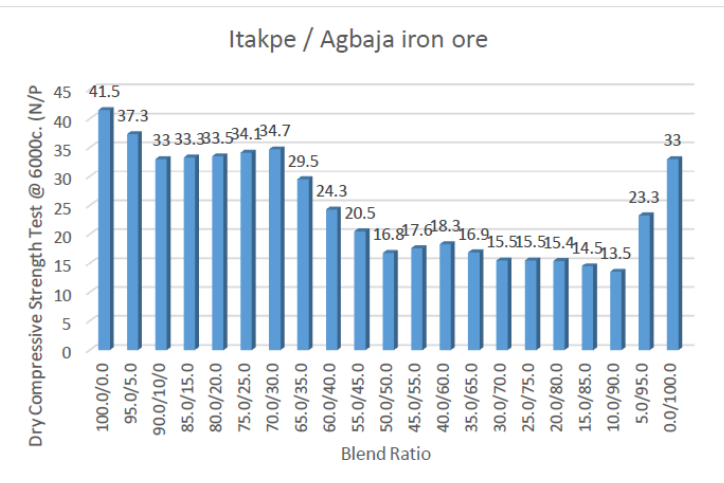

Figure2.04. Variation of Dry Compressive Strength with Various blends of Itakpe/Agbaja Iron Ore Pellets 


\subsection{Indurating Compressive Strength}

Figure2.05 shows Variation of Indurating Compressive Strength with various blends of of Itakpe/Agbaja Iron Ore Pellets. In this trend the best green compression strength amongst the blend mixtures was achieved at 70/30 Itakpe/Agbaja blend ratio with green compressive strength of $2613 . .33 \mathrm{~N} / \mathrm{P}$ as compared to the standard requirement of $2600 \mathrm{~N} / \mathrm{P}$.

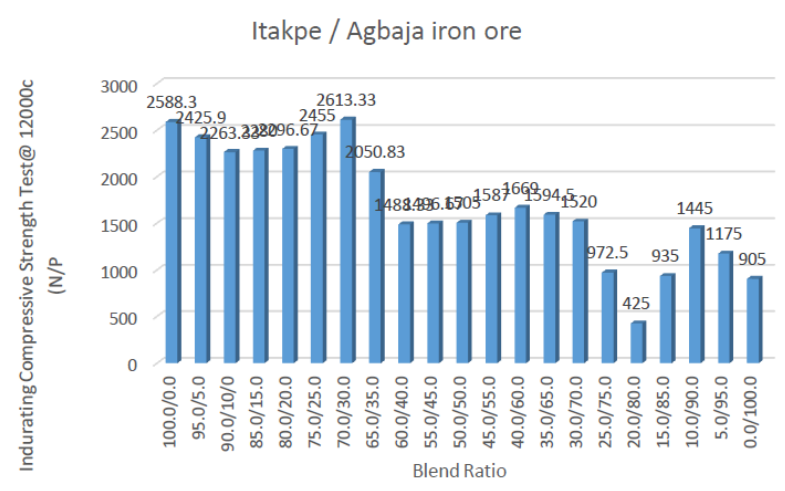

Figure2.05. Variation of Indurating Compressive Strength with various blends of Itakpe/Agbaja Iron Ore Pellets

\subsection{Moisture Content}

Figure 2.06 shows variation of moisture content with various blends of Itakpe/Agbaja iron ore pellets Itakpe/Agbaja blend ratios of 50/50 has moisture content value of $5.36 \mathrm{ml}$. However, the blends did not meet the standard requirement of $9.3 \mathrm{ml}$.

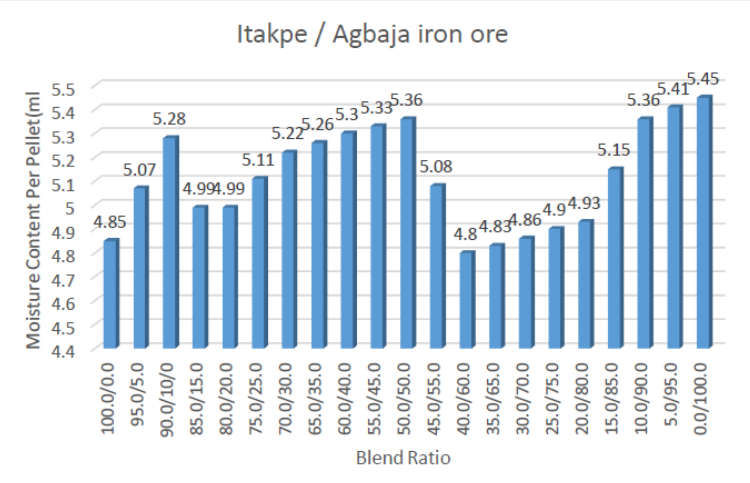

Figure2.06. Variation of Moisture Content with Various blends of Itakpe/Agbaja Iron Ore Pellets.

\subsection{Tumbler Index Value}

Figure2.07 shows variation of tumbler index with various blends of Itakpe/Agbaja iron ore pellets. Itakpe/Agbaja blend ratio of $40 / 60$ has tumbler index value of 97.01 percent both blends attained the standard requirements of 94 percent.

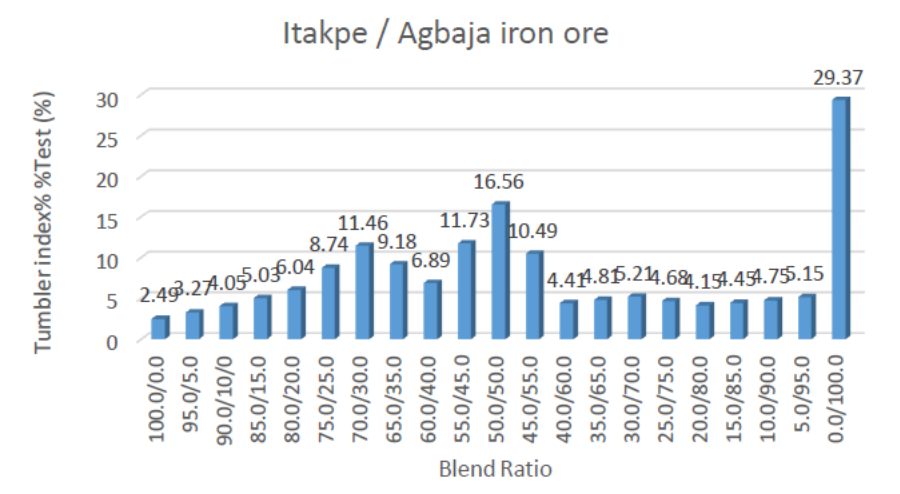

Figure2.07. Variation of Tumbler Index with various blends of Itakpe/Agbaja Iron Ore Pellets 


\subsection{Abrasion Index}

Figure2.08 shows variation of abrasion index with various blends of Itakpe/Agbaja iron ore pellet. Itakpe/Agbaja blend ratio of 50/50 gave abrasion index value of 16.56 percent. These two values of abrasion index are well above the standard value of 5 percent.

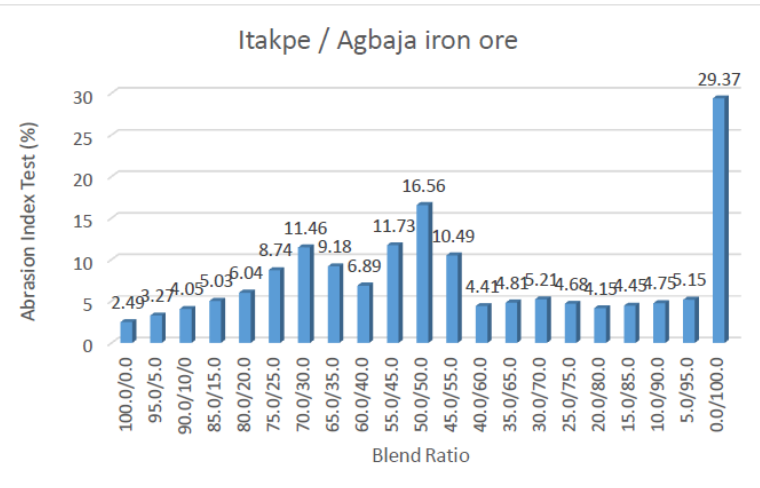

Figure2.08. Variation of Abrasion Index with various blends of Itakpe/AgbajaIron Ore Pellet

\subsection{Micro-porosity}

Figure2.09 shows the best micro-porosity point was achieved at Itakpe/Agbaja blend ratio of 10/90 with a value of 14.99 percent. According to the experiment this velocity is always so high that even porosity variation between $10-30 \%$ hardly cause great differences and the major part of pellets qualities is within the upper limit of this range.

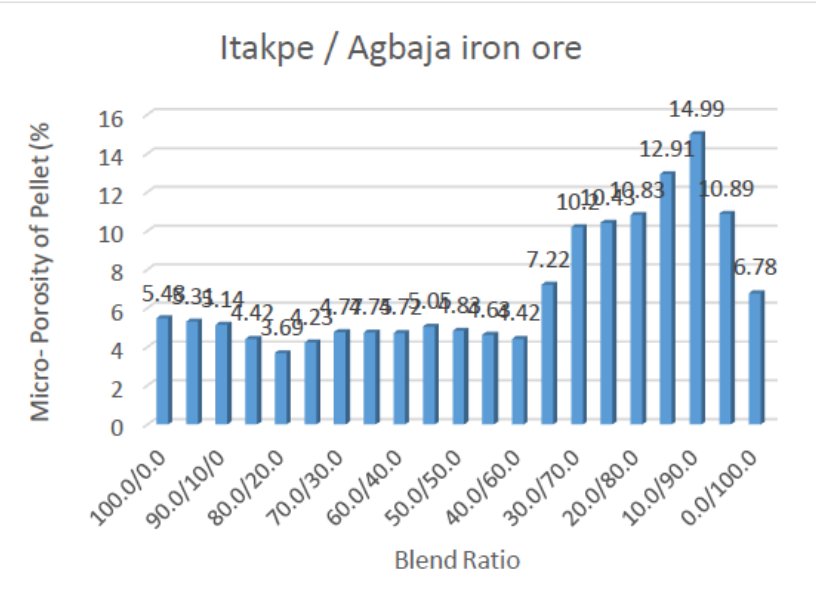

Figure2.09. Variation of Micro-Porosity with various blends of Itakpe/Agbaja Iron ore Pellet

\section{CONCLUSION}

Study on the reducibility and mechanical properties of pellets produced from blends of Itakpe and Agbaja iron ore from the finding of the study it was discovered that results and data obtained could be used for further study while the other iron ore deposits in the country could also be subjected to other exeperimental processes. Such ores could also be investigated and subjected to the reducibility processes and blending them with other ones with a view to generating the necessary data and to make comparism with those already investigated. The Delta Steel Company, Aldaja has in the past used the Itakpe iron ore as direct feed for the operation of the furnace which was discovered to contain haematite The Agbaja iron ore is lean and of sedimentary origin it was on these basis that the ore was blended with Itakpe iron ore in order to produce pellets for optimal results.

The study of the reducibility of the ores indicated Agbaja iron ironore could not reduce in both hydrogen and carbon monoxide atmosphere due to the presence of sinter hindering access while the Itakpe iron ore is most reduced. The study indicated that all the iron ore samples were found to be Oolithic in nature. The compressive strength results of the green pellets confirmed the presence of hygroscopic and hydrated waters. The Itakpe/Agbaja blend ratio of 70/30 gave the optimum 
indurating compressive strength of $2613.33 \mathrm{~N} / \mathrm{P}$ and therefore is best suitable .Sufficient mechanical strength of fired pellets for 70/30 Itakpe/Agbaja blend ratio was achieved. Finally it could be concluded that the research work was very successfully as a lot of experiences obtained from all the experiments performed.

\section{REFERENCES}

[1] B.L. English D.A \&Robert (1978) Trans. Inst. Min. Metali, Sect. C 87,113

[2] C.J Parks\& R.A McDiarmid. (1970) Ore Deposits, p. 245. W.H. Freeman Ltd.

[3] K.A Shehata. \& S.Y Ezz, (1973) Trans. Inst. Min. Metall. Sect. C 82, 38.

[4] K.A. Shehata. \&S.Y Ezz, (1973) Trans. Inst. Min. Metall. Sect. C 82, 38.

[5] N.H. Harbord \& D.CGoldring. (1965) 7. Iron and Steel Inst. 203,349

[6] N.J Pounds (1959) the Geography of Iron and Steel, p. 11. Hutchinson and Co. Ltd.

[7] P. Mihelik \& G. Smits, (1973) NIMReport 1565, Johannesburg, S. Africa.

[8] R. A. Mohammed, E.T. Dauda, S.B. Hassan, M. Abdulwahab (2014) "Assessment of Mechanical Properties of Pellets Produced From Itakpe/Agbaja Iron Ore Blends" A paper published in the Nigerian Metallurgical Proceeding at the $30^{\text {th }}$ Annual Conference and Annual General Meeting of the Nigerian Metallurgical Society at the Raw Materials Research and Development Council Abuja paper 14

[9] R. Robson (1968) ECA Paper A4 in: 2nd Int. Symp. on the Iron and Steel Industry. UNIDO, Moscow.

[10] R.P. Viswanath, B. Viswanath\& M.C. Sashtri M.C. (1977) Trans. Japan Inst. Metals 18, 149

[11] W.M McEwan (1962) Trans. Met. Soc. AIME 224, 387.

Citation: Ocheri C.et.al. (2018)" Study on the Reducibility and Mechanical Properties of Pellets Produced from Blends of Itakpe and Agbaja Iron Ore”, International Journal of Modern Studies in Mechanical Engineering, 4(3), pp.7-13. DOI: http://dx.doi. org/10.20431/2454-9711.0403002

Copyright: () 2018 Authors, This is an open-access article distributed under the terms of the Creative Commons Attribution License, which permits unrestricted use, distribution, and reproduction in any medium, provided the original author and source are credited. 